\title{
NEUROLOGICAL ASPECTS OF STUTTERING: SUMMARY OVERVIEW OF SCIENTIFIC FINDINGS
}

\section{Naudine Willemse}

$\mathrm{PhD}$ (Physiology)

Senior lecturer, Department Physiology, University of Pretoria

Corresponding author: nwillems@medic.up.ac.za

\author{
Margaretha Viljoen \\ $\mathrm{PhD}$ (Physiology) \\ Professor, Department Physiology, University of Pretoria
}

\section{Catherine Govender}

MSocSci (Psychology)

Keywords: stuttering; cerebral dominance; delayed maturation; hyper-/hypo-activation; neurological discoordination

\begin{abstract}
The aim of this article is to provide a summary overview of some of the more important scientific evidence of neurological differences between stutterers and non-stutterers. Stuttering is a complex disorder of speech fluency, the aetiology of which is still largely unclear. Although most of the knowledge about stuttering has been derived from clinical observations, essential information obtained through laboratory research delineated some important neurological differences between people with a stuttering problem and people who do not stutter. These differences are identified in terms of neuroimaging, speech production processes and even in terms of auditory perception and feedback mechanisms. The development of new and improved neuroimaging techniques has greatly enhanced the potential to investigate neurological correlates of stuttering. Current knowledge is indicative of a complex neurological basis for stuttering. However, on the basis of current scientific evidence any currently held theory cannot be conclusively substantiated.
\end{abstract}

\section{OPSOMMING}

Die doel van hierdie artikel is om 'n opsommende oorsig te bied van die belangrikste wetenskaplike bewyse vir neurologiese verskille tussen mense wat hakkel en mense wat nie hakkel nie. Hakkel is ' $n$ komplekse afwyking in die vloeiendheid van spraak. Die etiologie is nog grootliks onduidelik. Alhoewel die meeste kennis oor hakkel afgelei is van kliniese waarnemings, het essensiële inligting wat deur laboratoriumnavorsing verkry is daartoe bygedra om belangrike neurologiese verskille tussen mense wat hakkel en mense wat nie hakkel nie te identifiseer. Hierdie verskille kan beskryf word in terme van neurobeelding, die prosesse betrokke by spraakproduksie, klankwaarneming en terugvoermeganismes. Die ontwikkeling van nuwe en verbeterde neurobeeldingstegnieke maak dit vir die navorser moontlik om die neurologiese korrelate van hakkel te ondersoek. In die lig van huidige kennis kom dit voor asof hakkel ' $n$ komplekse neurologiese basis het. Nietemin, op grond van die beskikbare wetenskaplike feite kan geen van die huidige teorieë onweerlegbaar gesteun word nie.

\section{ABBREVIATIONS:}

ACC Anterior Cingulate Cortex

BA Brodmann's Area

MEG Magneto Electroencephalography

PET Positron Emission Tomography

PWS People With a Stuttering Problem 
PWnS

SMA
People With no Stuttering Problem

Supplementary Motor Area

\section{INTRODUCTION}

Stuttering is a disturbance in the fluency of speech marked by involuntary, audible or silent repetitions or prolongations of sounds or syllables (Büchel \& Sommer, 2004:E46). Speech impediments can have a significant impact on the psychological and, by implication, the physical health of the individual. In the fourth edition of the Diagnostic and Statistical Manual of Mental Disorders, communication disorders like stuttering are classified under Disorders Usually First Diagnosed in Infancy, Childhood, or Adolescence (American Psychiatric Association: Diagnostic and Statistical Manual for Mental Disorders, 1994:38). Stuttering can be affected by internal (or personal) as well as external (or environmental) factors. Therefore it can be classified under the World Health Organisation's International Classification of Functioning, Disability and Health (Yaruss \& Quesal, 2004:48). Stuttering is probably the most prevalent speech disorder and affects about $1 \%$ of prepubertal children (Andrews, Craig, Feyer, Hoddinott, Howie \& Neilson, 1983:228). Theories about the aetiology of stuttering span a continuum from the purely psychological to the physiological. Amongst the more important theories are a) the approach that stuttering is the result of learnt avoidance behaviour, as proposed by Sheehan (Sheehan, 1953, cited in Gregory, 1986:4; Van Riper, 1992:266, 297), b) the psychoanalytic approach that views stuttering as a neurotic tendency (Hahn, 1963), c) the Cerebral Dominance Theory (Orton, 1927:671, 672; Travis, 1978:277), d) the Excess Dopamine Theory Of Stuttering (Wu, Maguire, Riley, Lee, Keator, Tang, Fallon \& Najafi, 1997:767-770; Maguire, Riley, Franklin \& Gottschalk, 2000:482; Louis, Winfield, Fahn \& Ford, 2001), e) the Model of Central Nervous System Premotor Processing (Goldberg, 1985:567; Watson, Pool, Devous, Freeman \& Finitzo, 1992:559), and $f$ ) the Maturation Hypothesis of Stuttering (Özge, Toros \& Cömelekoglu, 2004:282). As early as the 1920s researchers began to suspect that stuttering has an organic basis but this has only been partially supported (Van Riper, 1992:353). According to Andrews et al. (1983:238) most theories about the breakdown of speech fluency stem from the proposition that people who stutter (PWS) have a reduced physiological ca- pacity to coordinate speech. This implies a neurological basis for stuttering. The latest findings point to the hyperactivation or deactivation of one or more areas of the central nervous system during speech, as well as impaired structural communication between the areas involved in speech production, which could possibly underlie the miss-timing and discoordination to cues from other speech areas (Ingham, 2001:501; Ingham, Ingham, Finn \& Fox, 2003:297; Peters, Hulstijn \& Van Lieshout, 2000:104). It is always easier to understand the abnormal against the background of the normal and, for the convenience of the reader, a recent model of the neural basis of normal speech production can therefore be found in Figure 1. For more information on the model the reader is referred to Jürgens (2002:251) and Ingham et al. (2003:300).

\section{CEREBRAL DOMINANCE}

The Cerebral Dominance Theory proposes stuttering as the consequence of a failure to establish dominance of the left hemisphere over the right. This concept was initially proposed by Orton (1927:671, 672), but continues to be debated to this day (Travis, 1978:275; Gelfer, 1996:155; Brosch, Haege, Kalehne \& Johanssen, 1999:71). An interesting observation implicating a difference in cerebral dominance between PWS and people who do not stutter (PWnS) has been reported with regard to ear preference, handedness and stuttering. While it is generally assumed that right-handed PWnS, display a right-ear preference $75 \%$ of the time, indicating left hemisphere dominance, Curry and Gregory (1969), showed that only $45 \%$ of right-handed PWS exhibited a right-ear preference in dichotic listening exercises (Curry \& Gregory, 1969, cited in Ingham, $2001: 494)$. This implication that PWS display less left hemispheric speech dominance than PWnS, has also been reported by others (Fox, Ingham, Ingham, Hirsch, Downs, Martin, Jerabek, Glass \& Lancaster, 1996:158; Braun, Varga, Stager, Schulz, Selbie, Maisog, Carson \& Ludlow, 1997:762). Another confounding factor is the fact that females on average show relatively less hemispheric dominance than males, thus one would expect stuttering to be more prevalent in female, yet chronic stuttering is not more common in females (Ingham, 


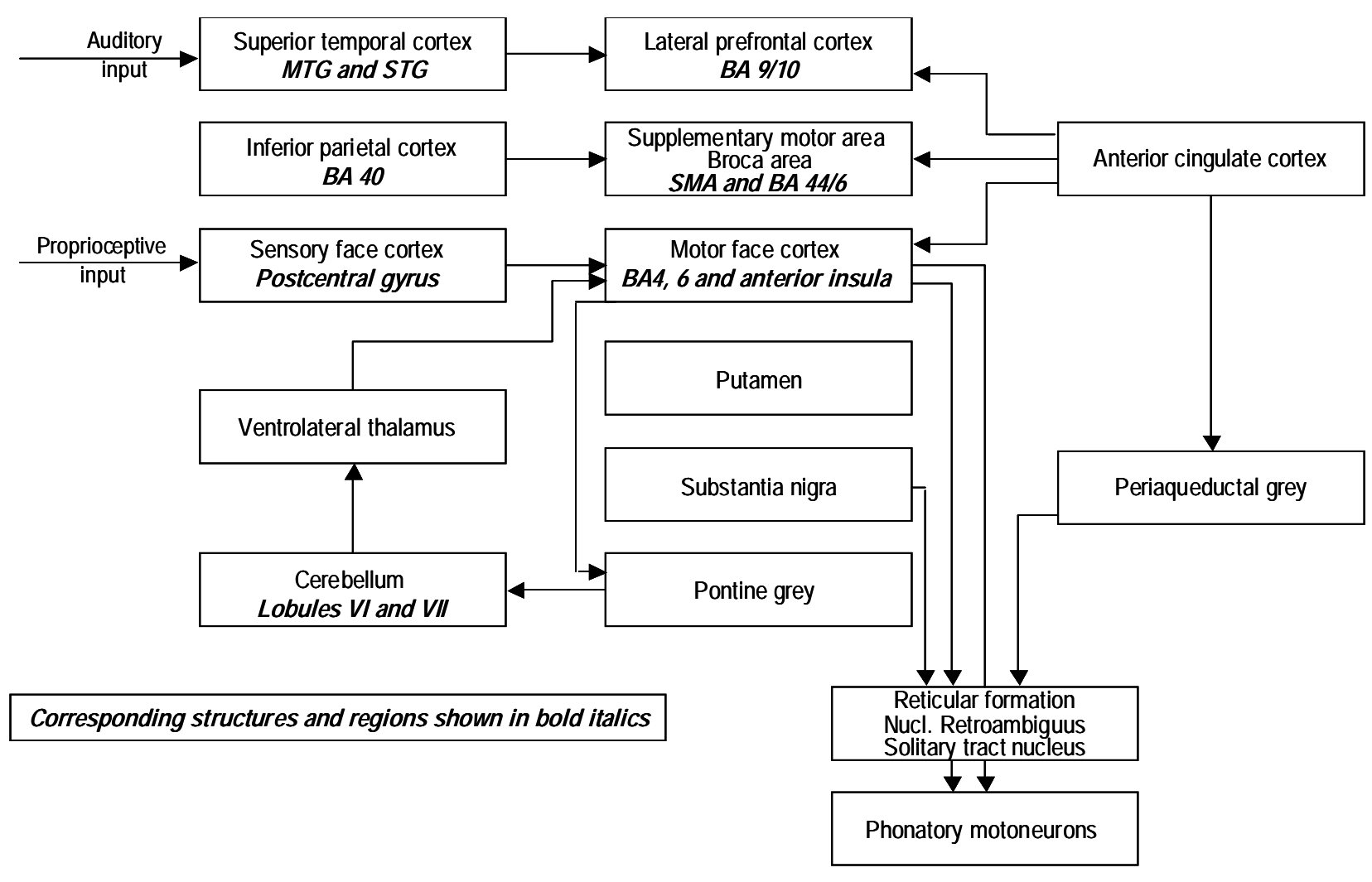

Figure 1: An adaptation of the Jürgens Model of speech production (reproduced with permission from Elsevier Inc.). The model shows areas implicated by various researchers to be involved in speech production. The arrows show anatomically confirmed direct connections. Auditory input refers to inputs of own speech as well as from others, and proprioceptive input comes form the larynx, articulatory organs and pulmonary stretch receptors (Jürgens, 2002:251; Ingham et al. 2003:300).

2001:494).

It appears that PWS show either bilateral dominance, as reported by Jones (Jones, 1966, cited in Van Riper, 1992:338), or right hemispheric dominance with regard to language (Braun et al. 1997:766). The results of Braun and co-workers were based on a comprehensive study of the patterns of cerebral activity that manifests during speech and language production, which showed that cerebral function is fundamentally different in PWS (Braun et al. 1997:761).

It is well-known that some individuals will cease to stutter at some stage, while the problem will persist in others. Brosch et al. (1999:240), who studied cerebral dominance in terms of chronicity of stuttering, proposed handedness to be related to the probability that a child's stuttering will become chronic. It would appear that lefthanded children show a significantly greater tendency towards chronic dysfluency. Although results from several laboratories support the concept of a link between stuttering and the pattern of cerebral dominance, with a higher incidence of stuttering in left-handers, workers such as Webster and Poulos (1987:708) could for instance not find evidence to suggest a higher incidence of left-hand preference in PWS than in PWnS. Thus further research is required for more definite conclusions on the role of cerebral dominance in stuttering.

Despite all these controversies, it does seem that the results of recent studies generally support the concept of abnormal interhemispheric relations and most point towards hyperactivity of the right, relative to the left hemisphere (Braun et al. 1997:762, 778; Büchel \& Sommer, 2004:e49; Neumann, Preibish, Euler, Von Gudenberg, Lanfermann, Gall \& Giraud, 2005:23). Neumann and co-workers reported abnormality in the white matter in the speech areas of the left hemisphere with hyperactivity of the right hemisphere (Neumann et al. 2005:23). Most of the recent conclusions are based on results of positron emission tomography, neuroimaging and functional magnetic resonance imaging. The concept of hyperactivity in the right hemisphere is further supported by the results of $\mathrm{H}_{2}{ }^{15} \mathrm{OPET}$ 
imaging studies during different speech tasks in stutterers and controls (Ingham et al. 2003:308). More evidence of differences between PWS and PWnS, with regard to hemispheric activity, is described under the discussion of neurological correlates of stuttering.

\section{NEUROLOGICAL CORRELATES OF STUTTERING}

Although conclusive evidence for specific cortical correlates of stuttering has, as yet, not been found, a pattern would appear to be surfacing (Sandak \& Fiez, 2000:446). A fairly general consensus exists that stuttering is a disorder that involves most of the multiple neural systems used for speech (Fox et al. 1996:158). Evidence is emerging that implicates cortical areas, such as the mouth presentation in the primary motor cortex (M1, Brodmann's area 4, BA 4), Broca's area (left inferior frontal region), the supplementary motor area (SMA, also known as Penfield's area), Brodmann's area 6 (BA 6, which is the SMA and superior lateral premotor region), the inferior lateral premotor cortex (BA $6 / 44)$, Wernicke's area, the auditory processing system, which includes the primary auditory cortex (BA 41/42), the auditory association cortex (BA 21/22), the anterior insula, the anterior cingulate cortex (ACC), as well as the somatic sensory area (Brodal, 1981:835; Fox et al. 1996:159). Some of the cortical areas involved are illustrated in Figure 2. In addition, subcortical areas such as the basal nuclei, the thalamus and cerebellum may all play a role in the mechanisms that bring about stuttering (Watson et al. 1992:560; Fox et al. 1996:159; Braun et al. 1997:776).

\section{Cortical areas}

When reading, impulses are sent from the occipital region to the angular gyrus where reading is changed to "hearing" and from here to Wernicke's area, where thoughts are formed. From Wernicke's area, these thoughts are sent to Broca's area via the arcuate fasciculus. The left inferior frontal regions, which include Broca's area, are involved in processing the information into a vocalisation pattern (Ganong, 2001:266), while the motor and premotor regions are involved in activating the motor response. In general, PWS exhibit hypo-activity in cortical areas associated with language processing, but hyperactivity in areas associated with motor function (Sandak \& Fiez, 2000:446).
Magneto electro-encephalogram (MEG) investigations also showed that, when PWnS read aloud, activation of the cortical areas involved occurs in the order of occipital areas to left inferior frontal areas (Broca's area) to premotor (for articulatory programming) and motor cortices (for motor preparation). PWS, on the other hand, exhibit a slightly altered pattern, that is, occipital region to premotor and motor regions to left inferior frontal areas (Broca's area) (Sandak \& Fiez, 2000:447; Salmelin, Schnitzler, Schmitz \& Freund, 2000:1184). On the grounds of this observation it was postulated that PWS initiate vocalisation patterns before the articulatory code is prepared (Sandak \& Fiez, 2000:447).

Another theory is that stuttering can be characterised as a disorder in the timing and coordination of subsystems involved in speech production (that is respiration, phonation and articulation). The research of $\mathrm{Pe}$ ters et al. (2000:103) has shown that, while PWS and PWnS, may perhaps not differ in the way they assemble speech-motor plans, the way in which they initiate those plans, however differs. Electromyogram (EMG) recordings of laryngeal and articulatory muscle activity during stuttering correlate highly with neurological findings (Peters et al. 2000:104). This begs the questions that if a discoordination of speech initiation exists in PWS, why do PWS not stutter all the time? PWS move along a continuum extending from normal speech movements to excessive deviances (Peters et al. 2000:105). The degree of fluency would largely depend on the nature of the task. When PWS are asked to perform relatively difficult (dysfluency-evoking) tasks, for example, spontaneous speech, there is a processing overload in the left inferior frontal areas. The result is dysfluent speech. During the performance of relatively easy tasks, the degree of activation required in Broca's area decreases, while fluent speech is produced (Sandak \& Fiez, 2000:448). It should, however, be obvious to anyone involved with this kind of speech impediment that other factors such as emotional and cognitive elements would also come into play. It seems feasible to suggest that the effects of emotions on the respiratory pattern - known to occur in most people, whether they suffer from speech dysfluency or not could contribute to the exacerbation of dysfluency in PWS.

It is generally accepted that Broca's and Wernicke's areas which, in right-handed individuals, are predomi- 


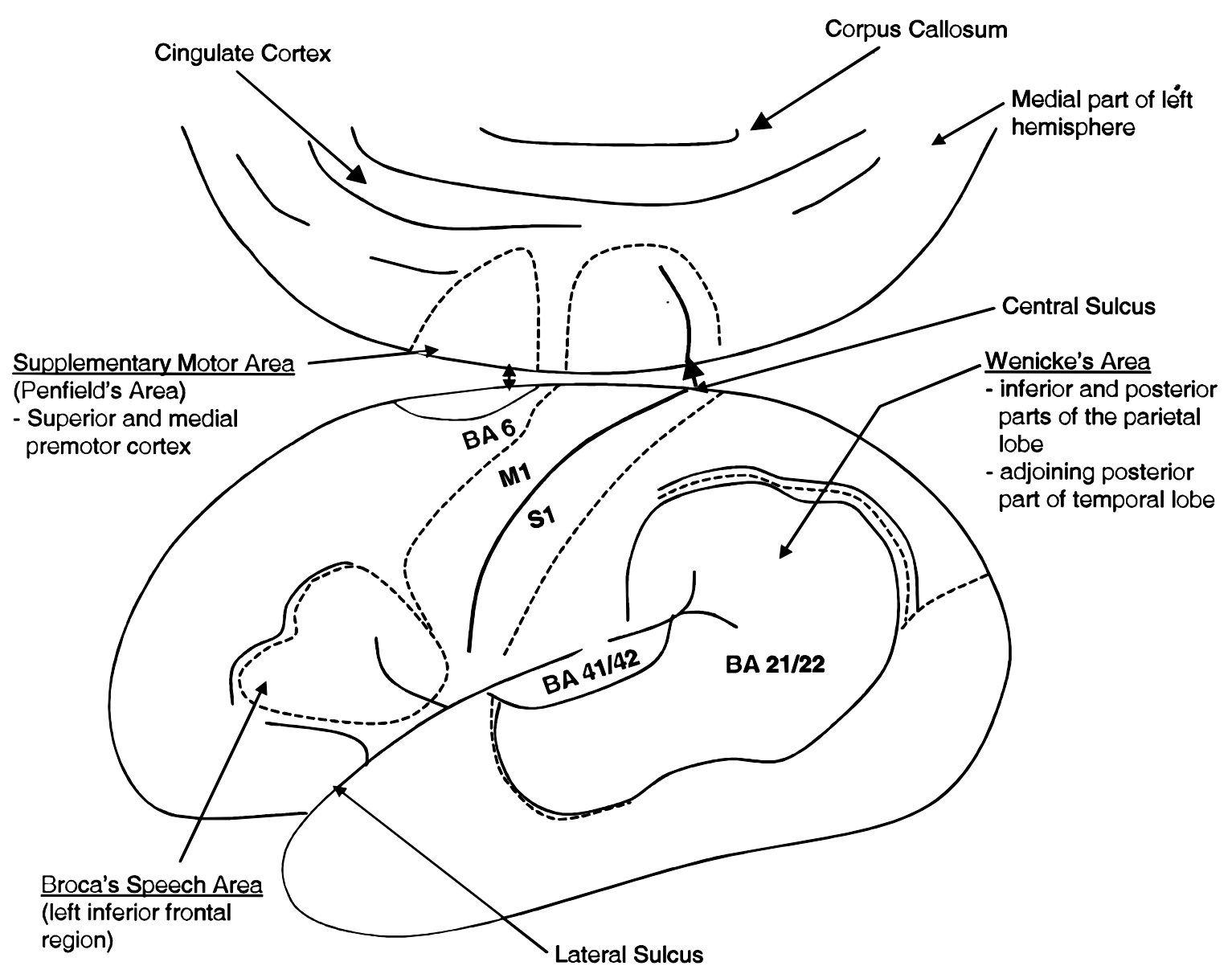

Legends: $\quad$ M1 = Primary motor cortical areas (precentral gyrus)

S1 = Primary sensory cortical areas (postcentral gyrus)

BA6 $=$ Brodman's area 6 (consists of SMA and superior lateral premotor area)

BA41/42 = Primary auditory area (temporal lobe)

BA21/22 = Auditory association area

Figure 2: Left hemisphere cortical regions involved in language mechanisms (Brodal, 1981:835; Fox et al. 1996:159)

nantly found in the left hemisphere, are involved with stuttering, but many other areas are also implicated, including the SMA, anterior insula and cerebellum (Goldberg, 1985:567; Ingham, 2001:498). The central portion of Wernicke's area (BA 22) is said to be inactive in PWS (Braun et al. 1997:766). In 1985, Goldberg proposed a model of central nervous system premotor processing (Goldberg, 1985:567; Watson et al. 1992:559). This model has since been used to explain stuttering in terms of a disruption in this processing system, implicating a dysfunction in the SMA as the cause of stuttering (Watson et al. 1992:559; Chung, Im, Lee \& Lee, 2004:1106). In a positron emission tomography (PET) study of chorus and solo reading in PWS and fluent controls, researchers found that PWS show a prominent right hemisphere hyperactivation of BA 6, which includes the SMA and the superior lateral premotor region (Fox et al. 1996:161). It was noticed that if stuttering was reduced after treatment, this activity shifted to the left hemisphere (Ingham, 2001:494,496). The same authors also described hypoactivity of the primary auditory areas (BA 41/42) and a largely deactivated auditory association area (BA $21 / 22$ ), especially in the right hemisphere (Ingham, 2001:496). This supports previously published results by Sandak and Fiez (2000:446), mentioned earlier in this section. These abnormal activations and deactivations associated with PWS were found to occur even when the PWS are merely imagining that they were stuttering, while reading silently (Ingham, 2001:498). 
However, these results could not be supported by cerebral blood flow (CBF) patterns for PWS and PWnS when not speaking (Braun et al. 1997:761; Ingham, 2001:498). Differences in CBF patterns apparently only occur when PWS actually speak (Ingham, 2001:498).

Slightly different patterns of cortical abnormalities are reported between female PWS and male PWS. There seems to be similar levels of activation in the SMA of female PWS and female PWnS (Ingham, 2001:499). Male PWS, on the other hand, display different levels of activation to both groups. Inconsistencies in the activity of the anterior insula, an area known to be important in the planning of phonation, occur in PWS. Although increased activity of the anterior insula has been reported during stuttering in both genders, the activity appears to be higher in the left hemisphere of females (Ingham, 2001:499).

There are some inconsistencies in reports on the activity of the anterior cingulate cortex (ACC). This area aids in speech motor activities and is of interest to many theories of stuttering. Researchers, who suggest that the right inferior ACC is hyperactivated during speech of PWS, but not in the speech of PWnS, include Braun et al. (1997:768) and Ingham et al. (2003:312). This view is supported by evidence from neuroimaging that shows increased regional CBF to the inferior and superior anterior cingulate cortex when PWS speak (Braun et al. 1997:769). The work of Fox et al. (1996:161) does however, not support this idea of activation of the ACC in PWS. These conflicting results may be due to taskrelated experimental differences between the different laboratories, as it is known that ACC activation diminishes as task familiarity increases (Petersen, Van Mier, Fiez \& Raichle, 1998:853; Ingham, 2001:501).

As mentioned previously, the somatic sensory area is implicated as one of the cortical areas involved in speech disorders such as stuttering. It appears that most PWS do not use their somatic sensory information in full for orofacial movements. These findings of De Nil and Abbs (1991:2145) could explain some breakdowns in speech.

A right hyperactivity, similar to that mentioned under cerebral dominance, has also been reported with regard to the insula. It is known that the left insula cortex forms an anatomical bridge between Broca and Wernicke's areas, that most speech functions involve the dorsal left anterior insula, and that damage to the left insula contributes to dyspraxia (Ingham et al. 2003:312). It was therefore suggested that excessive activity in the right insula cortex of PWS during speech might be due to a takeover of the left insula's speech functions by the right insula (Ingham et al. 2003:312).

Recently a different interpretation of the hemispheric left-hypoactivity-right-hyperactivity view was proposed by Özge et al. 2004:269. They also investigated the possible role of delayed cerebral maturation, hemispheric asymmetry and regional brain differences by means of conventional EEG and quantitative EEG in children who stutter. In contrast to the view of most that hyperactivity of the right hemisphere reflects compensation for the primary hypoactivity of the left, they suggested a primary right hemispheric defect, possibly right frontal region, which may be related to SMA. Their results also give some support to the maturation hypothesis that suggests stuttering to be at least partially due to a delay in cerebral maturation (Özge et al. 2004:270, 282). This concept that stuttering may be the result of delayed maturation dates to the 1940s when Karlin (1947) and others before him believed that the delayed myelinisation process of the cortical areas subserving speech and language in male children compared to female children, may be the cause of the higher incidence of stuttering in males (Karlin, 1947, cited in Van Riper, 1992:42). Previously in this discussion a possible association between handedness and the potential to outgrow childhood stuttering was mentioned (Özge et al. 2004:282). Another view about recovery from childhood stuttering relates to the abovedescribed concept of stuttering as a consequence of delayed cerebral maturation where recovery is suggested to reflect the eventual maturation of the mechanisms of speech motor control (Forster \& Webster, 2001:125).

\section{Subcortical Areas}

Subcortical areas implicated in stuttering are the basal nuclei, parts of the thalamus, as well as the cerebellum (Fox et al. 1996:161). The cerebellum, especially the vermis and the paramedian regions, is involved in the control of laryngeal and respiratory mechanisms during speech (Holmes, 1939). Lesions of the cerebellum could therefore disrupt the coordination of the muscles involved in speech. Several research groups 
reported enhanced cerebellar activity in PWS. De Nil, Kroll and Houle (2001:79) investigated the activity of the cerebellum of a control group of PWnS and a group of PWS. Cerebellar activity was measured before and after participation in an intensive programme to ameliorate stuttering. PWS were found to exhibit higher cerebellar activation than PWnS, both pre- and postprogramme, and therefore this overactivity of the cerebellar motor system has been included in the neural system of stuttering (Fox et al. 1996:161). PET images of blood flow studies showed that the right cerebellum hemisphere is prominent (Fox, Ingham, Ingham, Zamrripa, Xiong \& Lancaster, 2000:1985).

The role of the basal nuclei in language processing has become of great interest since the late 1990s. These subcortical motor nuclei are generally known to be involved in the routine voluntary actions of speech production such as articulation (Lebrun, 1998:121) and if damaged, seem to impact negatively on such functions. This may affect mechanisms related to the execution and termination of auditory feedback, which is used in the control of voice frequency (Kiran \& Larson, $2001: 795)$. The involuntary muscle contractions, which often accompany dysfluency in PWS, are brought on directly by subcortical nuclei (Lebrun, 1998:121). It is assumed that the left putamen plays a role in articulation, specifically in the second language, which is normally learnt after a child's fifth year (Klein, Zatorre, Milner \& Evans, 1994:2295). The subputaminal nucleus, which is normally best developed on the left at the anterointermediate level, may be connected to the cortical speech area and it is hypothesised that progressive aphasia may be related to disorders of the subputaminal nucleus (Šimiæ, Mrzljak, Fucic, Winblad, Lovric \& Kostovic, 1999:73). It has also been reported that the basal nuclei may modulate the unaffected primary speech and language areas, which results in stuttering (Ludlow \& Loucks, 2003:273). In addition, dopamine, a major basal nuclei neurotransmitter, has been under research as a possible cause for stuttering. Many researchers support the Excess Dopamine Theory of Stuttering (Wu et al. 1997; Maguire et al. 2000:482; Louis et al. 2001). However, this theory is partially refuted by evidence that L-dopa, which causes an increase in the amount of dopamine in the brain, improves speech fluency in Parkinson patients (Koller, 1983:175; Leder, 1996:475). Thus, the hypothesis might be amended to state that speech dysfluencies may be related to ei- ther increases or decreases in dopamine levels in the brain (Goberman \& Blomgren, 2003:55), in other words, aberrant levels of dopamine release. A perhaps more feasible possibility, well reviewed by Alm (2004:325, $355)$, is that the basal nuclei's contribution to stuttering may be multifactorial. The core dysfunction in this proposed multifactorial contribution is seen as an impaired ability of the basal ganglia to produce timing cues with contributing defects found at receptor level, for example, high density D2-receptors and a low D1/ $\mathrm{D} 2$ ratio in the putamen, as well as abnormalities in the basal ganglia-thalamocortical circuit (Alm, 2004:325, 355).

Contradicting results have been reported with regard to the thalamus. Some researchers reported the production of stuttering-like behaviours upon stimulating the ventrolateral thalamic region (Penfield \& Welch, 1951; Ojemann \& Ward, 1971:679). A more anterior part, as well as the pulvinar (posterior) part of the dominant hemispheric thalamus has also been associated with language disturbances (Penfield \& Roberts, 1959). In contrast, Bhatnagar and Andy (1989:1182) reported that stuttering could be reduced by thalamic stimulation.

Anatomical irregularities in speech motor areas such as the peri-sylvian speech and language areas have been reported in PWS. The exact implications of this are still unclear, but may be a cause for developmental stuttering (Foundas, Bolloch, Corey, Hurley \& Heilman, 2001:207). Doi, Nakayasu, Soda, Shimoda, Ito and Nakashima (2003:884) also reported that there are sites in the midbrain and upper pons, which, if lesioned, could cause stuttering. Closely related regions such as the frontal cortex and periaquaductal gray matter could be involved.

\section{CONCLUSIONS}

Ample empirical evidence exists to support the notion that stuttering can involve abnormalities of virtually any or all neural systems involved in speech, with a possible predominance of hypoactivity in the language processing areas and hyperactivity in the premotor and motor areas. In right-handed PWnS the left hemisphere is usually seen as the dominant hemisphere with regard to the cognitive aspects of speech. Indications are that this may not be the case in PWS and that suboptimal functioning of speech-related areas of the left 
hemisphere, whatever the cause, could lead to a compensatory hyperactivity in the right hemisphere. Preliminary indications are that abnormalities in the order of cerebral processing, as well as discoordination between the subsystems of speech initiation (respiration, phonation and articulation) may also be instrumental in the dysfluency of speech. Abnormalities of either cortical or subcortical systems may underlie the disturbances in coordination between these various systems. Although the implications are not quite clear it can, with a fair amount of certainty, be assumed that the hemispheric lateralisation of PWS differs from that of the rest of the population and that stuttering may perhaps be more prevalent in individuals with right hemispheric dominance. Various approaches try to explain age-dependent recovery from stuttering, but the most exciting explanation is that of delayed cerebral maturation. How this fits in with the other neurological correlates of stuttering is not clear, but the maturation hypothesis of stuttering leaves the door wide open for research of a more pragmatic nature by individuals who do not have high technology at their disposal.

In conclusion, it should be stressed that despite confirmation of the involvement of structural and functional abnormalities in dysfluency of speech, the possible contribution of psychological factors and the potential for correction through therapeutic intervention should not be disregarded. This is particularly relevant in view of the influence of early life experience on cerebral structure and function, as well as the fact that cerebral plasticity persists virtually throughout life.

\section{ACKNOWLEDGEMENT}

The authors would like to express their gratitude to $\mathrm{Mr}$ Cornelis van der Walt for the drawing of Figure 2.

\section{REFERENCES}

ALM, PA 2004: Stuttering and the basal ganglia circuits: a critical review of possible relations. Journal of Communication Disorders, 37(4):325-369.

AMERICAN PSYCHIATRIC ASSOCIATION 1994: Diagnostic and statistical manual for mental disorders $4^{\text {th }}$ edition. Washington DC: American Psychiatric Association.

ANDREWS, G; CRAIG, A; FEYER, A; HODDINOTT, S; HOWIE, P \& NEILSON, M 1983: Stuttering: A review of research findings and theories CIRCA 1982. Journal of Speech and Hearing Disor- ders, 48(August):226-246.

BHATNAGAR, SC \& ANDY, OJ 1989: Alleviation of acquired stuttering with human centremedian thalamic stimulation. Journal of Neurology, Neurosurgery and Psychiatry, 52(10):1182-1184. BRAUN, AR; VARGA, M; STAGER, S; SCHULZ, G; SELBIE, S; MAISOG, JM; CARSON, RE \& LUDLOW, CL 1997: Altered patterns of cerebral activity during speech and language production in developmental stuttering: $\mathrm{An}_{2}{ }^{15} \mathrm{O}$ positron emission tomography study. Brain, 120(5):761-784.

BRODAL, A 1981: Neurological anatomy. Oxford University Press: Oxford.

BROSCH, S; HAEGE, A; KALEHNE, P \& JOHANSSEN, HS 1999: Stuttering children and the probability of remission. The role of cerebral dominance and speech production. International Journal of Paediatric Otorhinolaryngology, 47(1):71-76.

BüCHEL, C \& SOMMER, M 2004: What causes stuttering? PloS Biology, 2(2):e46-55.

CHUNG, SJ; IM, JH; LEE, JH \& LEE, MC 2004: Stuttering and gait disturbance after supplementary motor seizure. Movement Disorders, 19(9):1106.

DE NIL, LF \& ABBS, JH 1991: Kinaesthetic acuity of stutterers and non-stutterers for oral and non-oral movements. Brain, 114(5):2145-2158.

DE NIL, LF; KROLL, RM \& HOULE, S 2001: Functional neuroimaging of cerebellar activity during single word reading and verb generation in stuttering and non-stuttering adults. Neuroscience Letter, 302(2-3):77-80.

DOI, M; NAKAYASU, H; SODA, T; SHIMODA, K; ITO, A \& NAKASHIMA, K 2003: Brainstem infarction presenting with neurogenic stuttering. Internal Medicine, 42(9):884-887.

FORSTER, DC \& WEBSTER, WG 2001: Speech motor control and interhemispheric relations in recovered and persistent stuttering.

Developmental Neuropsychology, 19(2):125-145.

FOUNDAS, AL; BOLLICH, AM; COREY, DM; HURLEY, M \& HEILMAN, KM 2001: Anomalous anatomy of speech-language areas in adults with persistent developmental stuttering. Neurology, 57(2):207214.

FOX, PT; INGHAM, RJ; INGHAM, JC; HIRSCH, TB; DOWNS, JH; MARTIN, C; JERABEK, P; GLASS, T \& LANCASTER, JL 1996: A PET study of the neural systems of stuttering. Nature, 382(July):158-161.

FOX, PT; INGHAM, RJ; INGHAM, JC; ZAMARRIPA, F; XIONG, JH \& LANCASTER, JL 2000: Brain correlates of stuttering and syllable production: A PET performance analysis. Brain, 123(10):19852004.

GANONG, WF 2001: Review of Medical Physiology; $20^{\text {th }}$ edition. Connecticut: Appleton \& Lange.

GELFER, MP 1996: Survey of communication disorders: A social and behavioural perspective. New York: McGraw-Hill. 
GOBERMAN, AM \& BLOMGREN, M 2003: Parkinsonian speech disfluencies: Effects of dopa-related fluctuations. Journal of Fluency Disorders, 28(1):55-70.

GOLDBERG, G 1985: Supplementary motor area structure and function: Review and hypotheses. Behavioural and Brain Sciences, 8(4):567-616.

GREGORY, HH 1986: The problem of stuttering: Where are we in 1986 ? South African Journal of Communication Disorders, 33:3-7.

HAHN, EF 1963: Stuttering: Significant theories and therapies. Stanford: Stanford University.

HOLMES, G 1939: The cerebellum of Man. Brain, 62(1):1-30. INGHAM, RJ 2001: Brain imaging studies of developmental stuttering. Journal of Communication Disorders, 34(6):493-516. INGHAM, RJ; INGHAM, JC; FINN, P \& FOX, PT 2003: Towards a functional neural systems model of developmental stuttering. Journal of Fluency Disorders, 28(4):297-318.

JüRGENS, U 2002: Neural pathways underlying vocal control. Neuroscience and Biobehavioral Reviews, 26(2):235-258. KIRAN, S \& LARSON, CR 2001: Effect of duration of pitch-shifted feedback on vocal responses in patients with Parkinson's disease. Journal of Speech, Language and Hearing Research, 44(5):975-987.

KLEIN, D; ZATORRE, RJ; MILNER, E \& EVANS, AC 1994: Left putaminal activation when speaking a second language: Evidence from PET. Neuroreport, 5(17):2295-2297.

KOLLER, WC 1983: Disfluency (stuttering) in extrapyramidal disease. Archives of Neurology, 40(March):175-177.

LEBRUN, Y 1998: Clinical observations and experimental research in the study of stuttering. Journal of Fluency Disorders, 23(2):119-122.

LEDER, SB 1996: Adult onset of stuttering as a presenting sign in a Parkinsonian-like syndrome: A case report. Journal of Communication Disorders, 29(6):471-478.

LOUIS, E; WINFIELD, L; FAHN, S \& FORD, B 2001: Speech disfluency exacerbated by levodopa in Parkinson's disease. Movement Disorders, 16(3):562-581.

LUDLOW, CL \& LOUCKS, T 2003: Stuttering: A dynamic motor control disorder. Journal of Fluency Disorders, 28(4):273-295. MAGUIRE, GA; RILEY, GD; FRANKLIN, DL \& GOTTSCHALK, LA 2000: Risperidone for the treatment of stuttering. Journal of Clinical Psychopharmacology, 20(4):479-482.

NEUMANN, K; PREIBISH, C; EULER, HA; VON GUDENBERG, AW; LANFERMANN, H; GALL, V \& GIRAUD, AL 2005: Cortical plasticity associated with stuttering therapy. Journal of Fluency Disorders, 30(1):23-39.

OJEMANN, GA \& WARD Jr., AA 1971: Speech representation in ventrolateral thalamus. Brain, 94(4):669-680.

ORTON, ST 1927: Studies in stuttering. Arch Neurology and
Psychiatry, 18:671-672.

ÖZGE, A; TOROS, F \& CöMELEKOGLU, Ü 2004: The role of hemispherical asymmetry and regional activity of quantitative EEG in children with stuttering. Child Psychiatry and Human Development, 34(4):269-285.

PENFIELD, W \& ROBERTS, L 1959: Speech and brain mechanisms. Princeton: Princeton University Press.

PENFIELD, W \& WELCH, K 1951: The supplementary motor area of the cerebral cortex: A clinical and experimental study. Archives of Neurology and Psychiatry, 66:289-317.

PETERS, HFM; HULSTIJN, W \& VAN LIESHOUT, PHHM 2000: Recent developments in speech motor research into stuttering. Folia Phoniatr Logop, 52(1-3):103-119.

PETERSEN, SE; VAN MIER, H; FIEZ, JA \& RAICHLE, ME 1998: The effects of practice on the functional anatomy of task performance. (In: Proceedings of the National Academy of Sciences of the United States of America, 95(3):853-860).

SALMELIN, R; SCHNITZLER, A; SCHMITZ, F \& FREUND, HJ 2000 :

Single word reading in developmental stutterers and fluent speakers. Brain, 123(6):1184-1202.

SANDAK, R \& FIEZ, JA 2000: Stuttering: A view from neuroimaging. Lancet, 356(9228):445-449.

ŠIMIÆE, G; MRZLJAK, L; FUÈIÈ, A; WINBLAD, B; LOVRIÆE, H \& KOSTOVIÆ, I 1999: Nucleus subputaminalis (Ayala): The still disregarded magnocellular component of the basal forebrain may be human specific and connected with cortical speech area. Neuroscience, 89(1):73-89.

TRAVIS, LE 1978: Neurophysiological dominance. Journal of Speech and Hearing Disorders, 43(3):275-277.

VAN RIPER, C 1992: The Nature of Stuttering; $2^{\text {nd }}$ edition. Long Grove: Waveland Press.

WATSON, BC; POOL, KD; DEVOUS, MD; FREEMAN, FJ \& FINITZO, T 1992: Brain blood flow related to acoustic laryngeal reaction time in adult developmental stutterers. Journal of Speech and Hearing Research, 35(June):555-561.

WEBSTER, WG \& POULOS, M 1987: Handedness distributions among adults who stutter. Cortex, 23(4):705-708.

WU, J; MAGUIRE, G; RILEY, G; LEE, A; KEATOR, D; TANG, C; FALLON, L \& NAJAFI, A 1997: Increased dopamine activity associated with stuttering. Neuroreport, 8(3):767-770.

YARUSS, JS \& QUESAL, RW 2004: Stuttering and the international classification of functioning, disability, and health: An update. Journal of Communication Disorders, 37(1):35-52. 